\title{
Studi Pemanfaatan Sampah Plastik Menjadi Produk dan Jasa Kreatif
}

\author{
Hijrah Purnama Putra dan Yebi Yuriandala \\ Jurusan Teknik Lingkungan, Fakultas Teknik Sipil \& Perencanaan, \\ Universitas Islam Indonesia \\ Jalan Kaliurang Km 14.4, Sleman, Yogyakarta, 55584 \\ email: hijrah_purnama@yahoo.com
}

\begin{abstract}
Abstrak
Sumber sampah terbanyak adalah berasal dari pemukiman, komposisinya berupa 75\% terdiri dari sampah organik dan hanya 25\% sampah anorganik. Sampah organik telah banyak dimanfaatkan sebagai bahan pembuatan kompos, briket serta biogas, tetapi sampah anorganik masih sangat minim pengelolaannya. Sampah anorganik sangat sulit didegradasi bahkan tidak dapat didegradasi sama sekali oleh alam, oleh karena itu diperlukan suatu lahan yang sangat luas untuk mengimbangi produksi sampah jenis ini. Sampah anorganik yang paling banyak dijumpai di masyarakat adalah sampah plastik. Pada tahun 2008 produksi sampah plastik untuk kemasan mencapai 925.000 ton dan sekitar 80\%nya berpotensi menjadi sampah yang berbahaya bagi lingkungan. Karena potensinya yang cukup besar, alangkah lebih baik untuk memanfaatkan sampah plastik ini menjadi produk dan jasa kreatif dalam rangka mengelola sampah plastik dengan baik, sehingga plastik benar-benar mendukung kehidupan kita. Sebagai produk kreatif, karya kreasi sampah plastik memiliki nilai komersial yang menjanjikan. Produk ini memiliki daya jual yang dapat menghasilkan keuntungan. Secara umum, bisnis ini terbagi dalam dua jenis, yaitu produk dan jasa.
\end{abstract}

Kata kunci: sampah, plastik, produk, dan jasa kreatif

\section{Pendahuluan}

Sampah akan terus diproduksi dan tidak akan pernah berhenti selama manusia tetap ada. Dapat dibayangkan bahwa jumlah sampah yang dihasilkan oleh penghuni bumi ini akan semakin meningkat. Sampah sendiri merupakan salah satu bentuk konsekuensi dari adanya aktivitas manusia dan volumenya berbanding lurus dengan jumlah penduduk. Apabila tidak ditangani secara efektif dan efisien, eksistensi sampah di alam tentu akan berbalik menghancurkan kehidupan sekitarnya. Alam memang memiliki andil besar dalam pengolahan sampah secara otomatis, terutama pada sampah organik. Namun, kerja keras alam dalam mengurai sampah secara natural sangat tidak berimbang dibanding berjuta ton volume sampah yang diproduksi setiap harinya, potensi sampah kota di beberapa kota di Indonesia ditampilkan pada Tabel 1 (Tim Penulis PS, 2008).

Permasalahan sampah merupakan hal yang krusial. Bahkan, sampah dapat dikatakan sebagai masalah kultural karena dampaknya terkena pada berbagai sisi kehidupan, terutama seperti kotakota besar seperti Jakarta, Semarang, Surabaya, Bandung, Palembang, dan Medan.

Sumber sampah terbanyak adalah yang berasal dari pemukiman, komposisinya berupa 75\% terdiri dari sampah organik dan sisanya adalah sampah anorganik. Sampah organik telah banyak 
dimanfaatkan sebagai bahan pembuatan kompos, briket serta biogas, tetapi sampah anorganik masih sangat minim pengelolaannya. Sampah anorganik sangat sulit didegradasi bahkan tidak dapat didegradasi sama sekali oleh alam, oleh karena itu diperlukan suatu lahan penumpukan yang sangat luas untuk mengimbangi produksi sampah jenis ini. Sampah anorganik yang paling banyak dijumpai di masyarakat adalah sampah plastik. Pada tahun 2008 produksi sampah plastik untuk kemasan mencapai 925.000 ton dan sekitar 80\%nya berpotensi menjadi sampah yang berbahaya bagi lingkungan (Kompas, 2009).

Tabel 1. Potensi sampah kota di beberapa kota di Indonesia

\begin{tabular}{|l|l|c|c|}
\hline No. & Kota & Jumlah Penduduk (jiwa)* & Potensi Sampah Kota (ton/hari) \\
\hline 1 & Jakarta & 9.783 .308 & 4.892 \\
\hline 2 & Surabaya & 2.913 .973 & 1.457 \\
\hline 3 & Bandung & 2.603 .855 & 1.301 \\
\hline 4 & Bekasi & 577.958 & 789 \\
\hline 5 & Tangerang & 1.466 .596 & 733 \\
\hline 6 & Semarang & 1.454 .932 & 727 \\
\hline 7 & Malang & 828.710 & 414 \\
\hline 8 & Surakarta & 543.079 & 267 \\
\hline 9 & Denpasar & 485.538 & 243 \\
\hline 10 & Yogyakarta & 442.824 & 221 \\
\hline 11 & Bogor & 308.246 & 154 \\
\hline 12 & Cirebon & 267.986 & 133 \\
\hline 13 & Sukabumi & 135.338 & 67 \\
\hline 14 & Magelang & 126.500 & 63 \\
\hline 15 & Cianjur & 105.931 & 53 \\
\hline
\end{tabular}

Sumber: NUDS (National Urban Development Strategy), 2003 dalam Sudradjat, 2006.

Ketersediaan kantung plastik di berbagai tempat tak dapat dipisahkan dari perkembangan industri dan konsumerisme. Dunia industri mengeksplorasi sumber bahan mentah dan menjadikannya produk pemuas kebutuhan manusia. Ketika sumber daya alam tidak lagi mampu memenuhi kebutuhan yang terus meningkat, industri beralih pada bahan-bahan sintetis. Material sistetis seperti rayon, nilon, akrilik, dan plastik menggantikan katun, wol, sultra, dan kayu dengan harga yang jauh lebih murah. Material ini dapat bertahan selamanya meski telah digunakan berulang kali, ringan, dan dapat diolah kembali menjadi bentuk yang baru dan tetap murah.

Berbagai industri di dunia menggunakan plastik untuk mengemas produk mereka. Industri makanan dan minuman instan misalnya, memilih plastik berlapis alumunium foil atau plastik multilayer sebagai kemasan karena dianggap aman dan dapat menjaga produk tetap layak dikonsumsi. Disamping itu, material pembungkus ini tidak membuat biaya produksi melonjak. Produsen tetap dapat menjual produk eceran dengan harga yang terjangkau. Hal yang sama juga dilakukan oleh produsen shampo, permen, susu dan obat-obatan. Plastik kemasan berlapis alumunium foil menggantikan kaca, kaleng, dan kertas sebagai material pengemas. 
Pada saat yang sama, produk-produk hasil industri melimpah, kebutuhan manusia menjadi lebih kompleks, masyarakat terus berbelanja dan membutuhkan tas untuk membawa barang-barang mereka. Plastik kemudian menjadi jawaban bagi kebutuhan ini, murah, kuat, ringan, tidak berkarat, bersifat termoplastis, dapat diberi label dengan berbagai kreasi, selalu dapat dibuat menarik, dan bisa menjadi sarana branding yang efektif. Anda dapat menemukan plastik dengan merk perbisnisan tertentu di supermarket, toko buku, butik, toko alat elektronik sampai toko perlengkapan bayi.

Sebelum kantong plastik muncul, manusia menggunakan tas dari bahan alami seperti rajutan akar, daun dan kain. Saat ini meskipun telah membawa tas yang cukup besar, banyak orang tetap meminta kantung plastik saat berbelanja. Plastik telah menjadi bagian dari gaya hidup kita.

Sejauh ini keterlibatan masyarakat dalam mengurangi pemakaian dan mendaur ulang plastik masih sangat minim. Biasanya plastik dibakar untuk memusnahkannya dari pandangan. Padahal, jika pembakaran plastik tidak sempurna (di bawah $800^{\circ} \mathrm{C}$ ) dapat membentuk dioksin, yaitu senyawa yang dapat memicu kanker, hepatitis, pembengkakan hati dan gangguan system saraf (Sirait, 2009).

Penulis melihat terdapat potensi untuk memanfaatkan sampah plastik menjadi produk dan jasa kreatif dalam rangka mengelola sampah plastik dengan baik, sehingga plastik benar-benar mendukung kehidupan kita. Tidak hanya ketika kita gunakan namun juga setelah kita gunakan. Salah satu upaya untuk mengurangi dampak buruk sampah plastik bagi lingkungan adalah dengan melaksanakan prinsip 3R dalam kehidupan sehari-hari, yaitu pengurangan pemakaian (reduce), pemakaian ulang (reuse), dan pendaur ulang (recycle).

\section{Sejarah Plastik}

Jika ada yang bertanya, material apakah yang membawa manfaat bagi kehidupan sekaligus membahayakan pada saat yang sama, selain api dan air, plastik adalah jawabannya. Plastik telah menjadi sabahat manusia selama hampir satu abad, ia terus diproduksi dan dimanfaatkan sampai saat ini. Sebagai material yang sulit diurai secara alami, idealnya tidak boleh ada plastik yang menumpuk di Tempat Pembuangan Akhir (TPA). Ketika produk dari plastik telah habis masa pakainya, ia dapat didaur ulang dan dimanfaatkan kembali.

Plastik merupakan material yang baru, secara luas dikembangkan dan digunakan sejak abad ke-20, tepatnya pada tahun 1975 diperkenalkan oleh Montgomery Ward, Sears, J.C. Penny, Jodan Marsh dan toko-toko retail besar lainnya (Marpaung, 2009). Plastik berkembang secara luar biasa penggunaannya dari hanya beberapa ratus ton pada tahun 1930-an, menjadi 150 juta ton/tahun pada tahun 1990-an dan 220 juta ton/tahun pada tahun 2005. Saat ini hampir tidak ada supermarket, toko atau warung di Indonesia yang tidak menyediakan kantung plastik (Anonim, 2009). 


\section{Jenis-Jenis Plastik}

Ada berbagai macam jenis platik. Plastik yang digunakan untuk membuat botol air mineral tentu berbeda dengan plastik untuk membuat mangkuk, sedotan, kursi, dan pipa. Untuk mengetahui jenis plastik yang digunakan sebagai material dasar sebuah produk kita bisa melihat pada symbol yang dicetak pada plastik. Simbol ini berupa sebuah angka (dari 1-7) dalam rangkaian tanda panah yang membentuk segitiga, biasanya dicetak dibagian bawah benda plastik. Setiap simbol mewakili jenis plastik yang berbeda dan membentuk pengelompokkan dalam melakukan proses daur ulang.

Tabel 2. Simbol-simbol Plastik (Pravitasari, 2009)

\begin{tabular}{|c|c|}
\hline Simbol & Karakteristik dan Contoh \\
\hline & $\begin{array}{l}\text { Polyethylene Terephthalate (PET, PETE) } \\
\text { PET transparan, jernih, dan kuat. Biasanya dipergunakan sebagai botol minuman (air } \\
\text { mineral, jus, soft drink, minuman olah raga) tetapi tidak untuk air hangat atau panas. } \\
\text { Serpihan dan pelet PET yang telah dibersihkan dan didaur ulang dapat digunakan untuk } \\
\text { membuat serat benang karpet, fiberfill, dan geotextile. Jenis ini biasa disebut dengan } \\
\text { Polyester. }\end{array}$ \\
\hline & $\begin{array}{l}\text { High Density Polyethylene (HDPE) } \\
\text { HDPE dapat digunakan untuk membuat berbagai macam tipe botol. Botol-botol yang } \\
\text { tidak diberi pigmen bersifat tembus cahaya, kaku, dan cocok untuk mengemas produk } \\
\text { yang memiliki umur pendek seperti susu. Karena HDPE memiliki ketahan kimiawi yang } \\
\text { bagus, plastik tipe ini dapat digunakan untuk mengemas deterjen dan bleach. Hasil daur } \\
\text { ulangnya dapat digunakan sebagai kemasan produk non-pangan seperti shampo, } \\
\text { kondisioner, pipa, ember, dll. }\end{array}$ \\
\hline & $\begin{array}{l}\text { Polyvinyl Chloride (PVC) } \\
\text { Memiliki karakter fisik yang stabil dan tahan terhadap bahan kimia, pengaruh cuaca, } \\
\text { aliran, dan sifat elektrik. Bahan ini paling sulit untuk didaur ulang dan biasa digunakan } \\
\text { untuk pipa dan kontruksi bangunan. }\end{array}$ \\
\hline & $\begin{array}{l}\text { Low Density Polyethylene (LDPE) } \\
\text { Biasa dipakai untuk tempat makanan dan botol-botol yang lembek (madu, mustard). } \\
\text { Barang-barang dengan kode ini dapat di daur ulang dan baik untuk barang-barang yang } \\
\text { memerlukan fleksibilitas tetapi kuat. Barang dengan kode ini bisa dibilang tidak dapat di } \\
\text { hancurkan tetapi tetap baik untuk tempat makanan. }\end{array}$ \\
\hline & $\begin{array}{l}\text { Polypropylene (PP) } \\
\text { PP memiliki daya tahan yang baik terhadap bahan kimia, kuat, dan memiliki titik leleh } \\
\text { yang tinggi sehingga cocok untuk produk yang berhubungan dengan makanan dan } \\
\text { minuman seperti tempat menyimpan makanan, botol minum, tempat obat dan botol } \\
\text { minum untuk bayi. Biasanya didaur ulang menjadi casing baterai, sapu, sikat, dll. }\end{array}$ \\
\hline & $\begin{array}{l}\text { Polystyrene (PS) } \\
\text { PS biasa dipakai sebagai bahan tempat makan styrofoam, tempat minum sekali pakai, } \\
\text { tempat CD, karton tempat telor, dll. Pemakaian bahan ini sangat dihindari untuk } \\
\text { mengemas makanan karena bahan styrine dapat masuk ke dalam makanan ketika } \\
\text { makanan tersebut bersentuhan. Bahan Styrine berbahaya untuk otak dan sistem syaraf } \\
\text { manusia. Bahan ini dibanyak negara bagian di Amerika sudah melarang pemakaian } \\
\text { tempat makanan berbahan styrofoam termasuk negara cina. }\end{array}$ \\
\hline & $\begin{array}{l}\text { Other } \\
\text { Plastik yang menggunakan kode ini terbuat dari resin yang tidak termasuk enam } \\
\text { golongan yang lainnya, atau terbuat dari lebih dari satu jenis resin dan digunakan dalam } \\
\text { kombinasi multi-layer. }\end{array}$ \\
\hline
\end{tabular}


Pengelompokan dan pengkodean seperti ini dikembangkan oleh The Society of the Plastic Industry (SPI), sebuah organisasi perdagangan di Washington D.C yang mewakili industri plastik di Amerika. Tujuan dari pengelompokan dan pengkodean ini adalah menyediakan system nasional yang konsisten untuk memudahkan pengelompokan plastik bekas bagi pendaur ulang plastik. Meskipun tidak wajib dilakukan, pengkodean ini telah menjadi prosedur standar untuk produk plastik yang dijual di Amerika dan Kanada. Di Indonesia sendiri pengkodean ini sudah lazim digunakan (Marpaung, 2009).

Sampai saat ini kita dapat menemukan 7 jenis plastik dengan simbol berbeda. Pada Tabel 2 adalah simbol-simbol plastik tersebut.

\section{Metodelogi Penulisan}

\section{Metode Pengumpulan Data}

Penulis dalam mengumpulkan data dalam daftar pustaka menggunakan metode pengumpulan data sekunder yaitu data yang diperoleh dari pihak lain, tidak langsung diperoleh penulis dari subjeknya. Data sekunder biasanya berwujud data laporan yang tersedia. Dalam hal ini, data sekunder diperoleh melalui buku, jurnal dan artikel.

\section{Metode Analisis Data}

Metode yang penulis gunakan dalam analisis data adalah metode deskriptif yaitu menyajikan data secara sistematis agar mudah untuk dimengerti.

\section{Analisis dan Sintesis}

Plastik adalah sumber daya yang masih dapat dimanfaatkan dalam jangka waktu yang lama dan dapat digunakan berulang kali. Teknologi daur ulang plastik sebenarnya telah lama dikenal, namun perilaku membuang sampah masyarakat mempersulit kelancaran daur ulang. Masyakarat masih mencampur sampah organik dan anorgank sehingga pemilahan sampah memakan waktu yang lama. Diantara tumpukan sampah yang kita hasilkan, pemulung harus memilih-milih sampah yang dapat didaur ulang dan menyetorkannya kepada pengepul. Seandainya saja kita mau berdisiplin memilah sampah tentu sampah-sampah kita, terutama sampah plastik, akan mudah didaur ulang.

Sebenarnya konsep dalam pengelolaan sampah sangatlah mudah, seperti yang telah dilakukan oleh Iswanto di Paguyuban Sukunan Bersemi, Yogyakarta. Konsep yang ditawarkan cukup sederhana yaitu pemilahan sampah menjadi 3 yaitu sampah organik, anorganik dan sampah plastik. Sampah 
organik diolah secara mandiri di tiap rumah menjadi kompos, sebagian sampah plastik dimanfaatkan menjadi kerajinan, dan sampah anorganik lainnya disalurkan ke pengepul untuk diolah kembali. Keberhasilan Sukunan menjalankan sistem sederhana ini secara kontinu terletak pada kekompakan, niat dan motivasi dari Tim Pengelola Sampah dan kerjasama dari seluruh elemen masyarakat. Tanpa kerjasama dan penerimaan yang baik, sistem ini tentu tidak dapat berjalan. Konsep ini dijalankan dengan 4 prinsip yaitu mandiri (dikelola masyarakat sendiri), produktif (menghasilkan sesuatu yang bernilai), komprehensif (seluruh sampah dapat diatasi), dan ramah lingkungan (pengelolaan sampah tidak mencemari lingkungan) (Pamungkas, 2006).

\section{Bisnis Kreasi Sampah Plastik}

Bisnis daur ulang sampah telah berlangsung sejak lama dan merupakan bisnis besar yang dijalankan secara sistematis. Meskipun menguntungkan, tidak semua orang tertarik mendalami bisnis ini. Untuk menjadi pebisnis daur ulang plastik, seorang perlu membangun sistem pengumpulan sampah yang baik, menjalin kerjasama dengan pemulung, memiliki fasilitas pengolahan sampah, serta mengenal pangsa pasar produk daur ulang plastik yang diproduksinya. Meskipun tetap menggunakan plastik sebagai bahan baku utama, bisnis kreasi sampah plastik yang penulis tawarkan tidak sekompleks bisnis daur ulang plastik yang bercorak industrial dan bisnis ini dapat dilakukan secara mandiri.

Sebagai produk kreatif, karya kreasi sampah plastik memiliki nilai komersial yang menjanjikan. Produk ini memiliki daya jual yang dapat menghasilkan keuntungan. Secara umum, bisnis ini terbagi dalam dua jenis, yaitu produk dan jasa. Dalam konteks bisnis kreasi sampah plastik, kedua jenis bisnis tadi dapat dilakukan. Dari sisi produk, bisnis ini menghasilkan produk-produk yang menjanjikan secara finansial. Dari sisi jasa, ide usaha dan produk yang dihasilkan ini dapat dikemas menjadi jasa workshop/pelatihan/seminar yang menguntungkan.

Tabel 3. Matrik sederhana dalam bisnis sampah plastik

\begin{tabular}{|l|l|l|l|l|}
\hline \multicolumn{2}{|c|}{ Produk } & \multicolumn{3}{c|}{ Jasa } \\
\hline Setengah Jadi & \multicolumn{1}{|c|}{ Siap Jual } & \multicolumn{1}{|c|}{ Workshop } & \multicolumn{1}{c|}{ Pelatihan } & \multicolumn{1}{c|}{ Seminar } \\
\hline Bahan & Tas, dompet, & Membuat tas, & Bagaimana & Bisnis, pemasaran, \\
pembuat & keranjang, & dompet, & membuat business & dan inovasi produk \\
produk jadi & tempat pensil, & keranjang, tempat & plan bisnis kreasi & ramah lingkungan. \\
& tempat koran, & pensil, tempat & sampah plastik, & $\begin{array}{l}\text { Peran pemerintah } \\
\text { dalam mendukung } \\
\end{array}$ \\
& alas kursi, tas & Koran, alas kursi, & pengelolaan usaha \\
& laptop & tas laptop & & bisnis ramah \\
& & & & lingkungan. \\
\hline
\end{tabular}


Workshop bisnis kreasi sampah plastik dapat menjadi ajang transfer materi yang bisa dikemas dengan semangat entrepreneurship sehingga peserta akan mendapat pengetahuan tentang produksi karya kreatif, tips dan trik bagaimana menjalankan bisnis sampah plastik. Pelatihan produksi kreasi sampah plastik memiliki peluang bagus di kota-kota besar. Area ini potensial karena ketersediaan bahan baku melimpah dan padat penduduk, sementara orang memerlukan pekerjaan/ide bisnis, baik itu mahasiswa, ibu-ibu PKK, karang taruna, komunitas anak muda kreatif.

Bisnis kreasi sampah plastik dapat menjadi salah satu gerakan pemberdayaan komunitas. Ini merupakan salah satu kekuatan produk yang dapat dikomunikasikan pada konsumen. Proses produksi yang dilakukan melibatkan banyak pihak, mulai dari pemulung, penjahit, tenaga administratif, dan lain-lain. Menjalankan bisnis sampah plastik berarti menambah lapangan pekerjaan dan membuka kemungkinan peningkatan kesejahteraan masyarakat. Ada hal yang positif jika konsumen mengetahui bagaimana dan oleh siapa produk dibuat. Contohnya adalah sebagai berikut: Ibu Kasmi merupakan pengusaha kerajinan dari sampah plastik “The Happy Trash Bag” (Group of The Deaf People) di Ciputat, Tangerang. Ia melatih dan mempekerjakan sejumlah anak tunarungu membuat kerajinan sampah plastik dan mempekerjakan ibu-ibu miskin di lingkungan sekitarnya. Pada produk yang dijualnya, Ibu Kasmi membubuhkan kertas bertuliskan keterangan dalam bahasa Inggris bahwa produknya dibuat oleh para tunarungu (Marpaung, 2009).

Selain sebagai informasi produk, keterangan ini memberikan informasi kepada konsumen bahwa pembelian yang dilakukannya ternyata mendatangkan kebaikan bagi pekerja yang terlibat dalam pembuatan produk. Hal ini dapat meningkatkan nilai jual produk, tetapi hal ini tidak menjadi faktor utama dalam penjualan karena harus tetap mengutamakan kualitas dari produk yang dihasilkan.

\section{Potensi Sampah Plastik}

Sampah plastik dapat dikreasikan menjadi karya kerajinan bernilai jual tinggi tanpa melakukan peleburan terlebih dahulu. Pengolahan dilakukan dengan menggabungkan lembaran-lembaran plastik menjadi bahan dasar, baik dengan menjahitnya atau menempelkannya pada material lain.

Bungkus plastik beralumunium foil sebagai bahan baku produksi kerajinan memiliki beberapa kelebihan antara lain:

1. Kuat. Plastik kemasan didesain oleh produsen makanan/minuman instan sebagai pembungkus produk yang cukup kuat melindungi produk di dalamnya. Disamping itu, plastik baru dapat terurai sempurna dalam waktu 80 sampai 300 tahun. 
2. Anti air. Plastik kemasan tentu dirancang untuk melindungi produk di dalmnya dari air dan udara.

3. Desain yang bagus. Setiap produsen ketika melempar produknya ke pasaran, tentu akan mengemasnya semenarik mungkin agar produknya digemari dan dibeli konsumen. Alasannya, karena pandangan pertama ketika berbelanja biasanya pembeli tertuju ke kemasan yang apik dan mencolok. Kemasan yang tertata apik dilihat dari paduan warna, huruf, dan gambar tentu dirancang sedemikian rupa oleh tenaga ahli khusus (Hermono, 2009).

4. Murah. Sampah plastik adalah barang buangan dari produk sekali pakai. Oleh karena itu seringkali dianggap tidak punya nilai lagi. Sampah plastik diperoleh secara gratis apabila kita pandaai menyusun strategi pengumpulannya.

5. Ringan.

6. Lentur, muda dibentuk dan dilipat. Dengan sifat ini kita dapat memanfaatkan plastik mirip dengan kain atau kertas (Marpaung, 2009).

Kelebihan plastik berlapis alumunium foil ini membuatnya fleksibel untuk dikreasikan. Secara sederhana bisa dikatakan bahwa lembaran plastik dapat diposisikan seperti pengganti kain untuk kerajinan. Lembaran plastik dapat diolah dengan cara yang tidak jauh berbeda dengan kain. Anda dapat menjahitnya, memotong dan menyambungnya kembali, melipat, menjepitnya dengan aksesoris dari metal, dan megkombinasikannya dengan material lain.

Mainkanlah imaji anda dengan lembaran-lembaran plastik yang dapat menggantikan kain atau lembaran plastik jadi. Kalau lembaran kain batik dapat dimanfaatkan menjadi tas laptop, lembaran plastik pun bisa. Anggaplah bahwa lembaran plastik sama sekali seperti kain tebal, hanya sedikit kaku dan berisik. Eksplorasikanlah segala kemungkinan yang muncul dan kaitkan dengan keunikan yang ditimbulkan jika plastik kemasan beraneka warna menjadi bahan bakunya.

Gambar 1, 2 dan 3 adalah beberapa contoh produk yang telah beredar di pasaran, dan penjelasan ciri khas masing-masing produk tersebut.

Bahan baku produk pada Gambar 1 didapat dengan cara mengumpulkan dari berbagai kantin yang ada di Kabupaten Sleman, Yogyakarta. Spesialisasi produknya adalah kemasan plastik beralumunium foil. Konsumennya telah tersebar di berbagai propinsi di Indonesia. Harga penjualan masing sangat terjangkau, mulai dari puluhan ribu hingga ratusan ribu rupiah.

Tas tangan, dompet dan kantung produksi Ecoist dibuat dari pembungkus permen, label minuman bersoda, dan bungkus makanan lainnya yang dibuang oleh pabrik karena kesalahan cetak atau 
kesalahan lainnya. Selain plastik pembungkus, Ecoist juga menggunakan majalah bekas dan plastik PVC sebagai bahan dasar. Produk pada Gambar 2 dibuat secara handmade di Mexico dan Peru. Nilai produk di negeri asalnya bisa mencapai ratusan dollar.

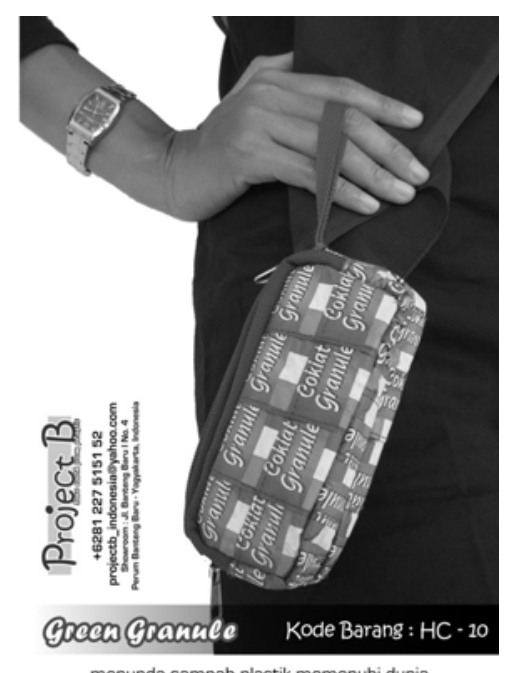

Gambar 1. Produk kerajinan sampah plastik dari Project B Yogyakarta (sumber: http://www.facebook.com/photo.php?pid=100144804\&op=1\&o=global \&view=global\&subj=1205208724\&id=1205208724)

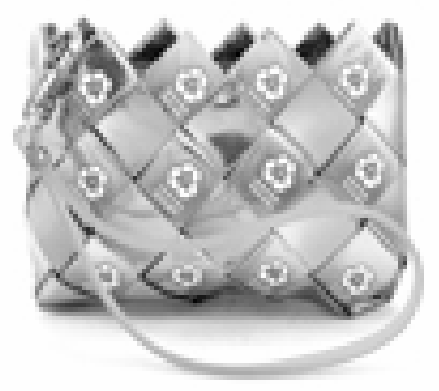

Gambar 2. Produk kerajinan sampah plastik dari Ecoist (sumber : http://www.ecoist.com)

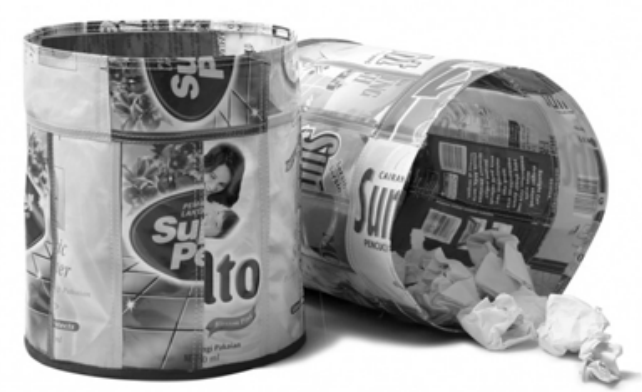

Gambar 3. Produk kerajinan sampah dari Xs Project (sumber : www.xsprojectgroup.com)

Sampah plastik yang digunakan dalam Xs Project (Gambar 3) dikumpulkan oleh komunitas pemulung dan pemungut sampah di Jakarta. Meterial ini kemudian diolah menjadi berbagai produk oleh tenaga outsource dan pengrajin yang dipekerjakan oleh Xs Project. 
Plastik sudah menjadi bagian dari kehidupan kita. Setiap hari kita banyak menggunakan produkproduk yang mengandung plastik. Banyaknya plastik yang kita gunakan menghasilkan sampah yang melimpah. Pernahkah terfikir oleh kita, berapa banyak plastik yang akan digunakan setiap hari, setiap minggu, dan setiap tahunnya? Jika anda mau meluangkan waktu menghitungnya, dalam 5 tahun saja anda telah mengkonsumsi setidaknya 3.650 lembar kantung plastik. Bayangkan, jika 200 juta penduduk Indonesia melakukannya setiap hari, berapa ton kantung plastik yang beredar dalam setahun? Diperkirakan warga Jakarta saja dapat membuang kantong plastik yang bisa menutupi lebih dari 200 lapangan sepak bola (Marpaung, 2009), sumber lain menyebutkan bahwa 1.500 lembar sampah plastik dihasilkan setiap detik di Jakarta (Hermono, 2009).

Kegiatan di atas adalah salah satu contoh dari proses daur ulang plastik (recycle) yang bertujuan untuk mengubah penggunaan barang plastik supaya tetap bermanfaat, misalnya dengan membuat tas atau produk berguna dan bernilai jual. Selain itu dapat juga dilakukan kegiatan pengurangan pemakaian (reduce) yang bertujuan meminimalkan jumlah plastik yang akan berakhir menjadi sampah setiap hari, misalnya dengan mengurangi barang-barang yang menggunakan plastik. Langkah lain yang dapat juga dilakukan untuk meminimalkan penggunaan plastik baru adalah pemakaian ulang (reuse) bertujuan untuk memaksimalkan penggunaan barang plastik yang sudah ada, misalnya dengan menggunakan kantong plastik yang sudah ada sebelumnya yang masih berfungsi dengan baik.

\section{Kesimpulan}

Setelah melalui proses analisis dan sistesis masalah, maka kesimpulan yang didapatkan dari penelitian studi literatur ini adalah sampah plastik memiliki bahaya yang cukup besar bagi keberlangsungan hidup manusia, oleh karena itu diperlukan suatu usaha yang serius oleh berbagai pihak untuk mengelolanya. Karena disamping bahaya yang ditumbulkannya, plastik sekaligus memiliki potensi yang menjanjikan untuk dikembangkan sebagai produk dan jasa kreatif.

Kegiatan kreasi sampah plastik ini juga dapat menjadi salah satu gerakan pemberdayaan komunitas dan memperluas lapangan pekerjaan dan membuka kemungkinan peningkatan kesejahteraan masyarakat.

\section{Daftar Pustaka}

Anonim. (2009). Plastik. didownload dari http://id.wikipedia.org/wiki/Plastik

Anonim. (2009). Sampah Plastik Jadi Limbah. didownload dari http://cetak.kompas.com/ $\mathrm{read} / \mathrm{xml} / 2008 / 08 / 06 / 00444748 / 80$.persen.sampah.plastik.jadi.limbah 
Ecoist. (2009). Produk Sampah Kemasan. didownload dari http://www.ecoist.com

Hermono, Ulli. (2009). Inspirasi dari Limbah Plastik. Kawan Pustaka. Jakarta.

Marpaung, G.S., dan Widiaji. (2009). Raup Rupiah dari Sampah Plastik. Pustaka Bina Swadaya. Jakarta.

Pamungkas, T.A. (2006). Iswanto: Bukan Membuang tapi Mengelola, dalam Sampah Dilema Manusia Modern dan Krisis Ekologi. Balairung Jurnal Mahasiswa Universitas Gadjah Mada. Edisi 39. Yogyakarta.

Pravitasari, Anita. (2009). Simbol Daur Ulang pada Botol dan Kemasan Plastik, didownload dari http://majarimagazine.com/2009/02/simbol-daur-ulang-pada-botol-dan-kemasan-plastik/

Project B. (2009). Produk Sampah Kemasan, didownload dari http://www.facebook.com/ photo.php?pid=100144804\&op=1\&o=global\&view=global\&subj=1205208724\&id=12052 08724

Sirait, Mita. (2009). Sulap Sampah Plastik Lunak jadi Jutaan Rupiah. B-Frist. Yogyakarta.

Sudradjat, H.R. (2006). Mengelola Sampah Kota. Penebar Swadaya. Jakarta.

Tim Penulis PS. (2008). Penanganan dan Pengolahan Sampah. Penebar Swadaya. Jakarta.

Xs Project. (2009). Produk Sampah Kemasan. didownload dari www.xsprojectgroup.com 